\title{
Donald Weber
}

Selling Dreams.

Advertising Strategies From Grands Magasins to Supermarkets in Ghent, 1900-1960

Notwithstanding a recent upsurge of interest in the history of the department store, the problem of definition is yet unsolved ${ }^{1}$. Capturing the nature of this central institution in the transformation of consuming habits appears as a crucial problem. In a recent review of new studies on consumption history, it is being pointed out that 'recognition of the dynamism of earlier retail environments; the extent of consumers' pre-existing skills [...]; and the sophistication of earlier consumption cultures blurs distinctions between department stores and earlier shops'. Recent studies, it is being stated, 'draw attention to consumers' own practices and knowledge at the expense of advertising images, as sources of the meaning of objects'. The author favours the argument of a 'greater integration of manipulationist and voluntarist accounts of consumer culture'2. What this makes clear is that the history of the grands magasins should go beyond the limits of the institution and its commercial practices, and be situated in a wider economic and cultural frame.

First of all, there is no dilemma between the new commercial strategies of the stores and the cultural preferences of their bourgeois customers. The history of the grands magasins starts humbly: its direct predecessors were small shops in clothing, maisons de nouveautés, stores for household tools and all sorts of stuff for interior decoration, small traders in chinaware and crystal objects... in other words, anything that was fashionable. Fashion is the pattern resulting of the strivings of many individuals for the pleasures of new experiences (e.g. the wearing of a new dress), without any central authority imposing criteria for novelty ${ }^{3}$. If this desire for novelty, characteristic of modernist Western culture, could be directed materialistically towards the possession and use of new objects, it would make up a promising source for profit-making. This is what small tradesmen found out since the eighteenth century ${ }^{4}$. As a result a new dimension was added to the old process of exchange known as 'commerce': desire. Goods could be emotionally promising besides rationally useful; seduction would be as good a commercial strategy as conviction ${ }^{5}$. This was necessarily paralleled by the surge of a stratum of the population that was modernist enough to long for novelty, materialist enough to project this upon objects, and prosperous enough to be able to afford those. In other words, part of the young nineteenth-century bourgeoisie. The successful commercialization of their modernist lifestyle is what we call today 'consumer society'. The specific historical role of the grands magasins follows directly out of their capacity to fuse modernist bourgeois culture and commercial mass production into a dream marriage ${ }^{6}$. The department store and the bourgeois enjoyed an interactive relation: bourgeois modernism was shaped out of a romantic heritage in an era of profound technological and commercial changes, of which the department store was a part. The latter in their turn adapted to the preferences of their customers, but at the same time fulfilled a role in a broader environment of institutions and practices that helped shape bourgeois culture.

Second, the department store should not be seen separated from its natural environment, the whole of the retailing sector within a changing economy. The central feature of the grand magasin was its concentration of capital, enabling the store to enjoy the advantages of an economy of scale. The upsurge of department stores in the second half of the nineteenth century was reflecting the ongoing urbanization, accompanied by the development of new means of urban transport ${ }^{7}$. As such, the construction of the big city store offering a diversified range of goods was not the invention of a ingenious tradesman, rather it was a function of the social phenomenon of an ever denser and more mobile population in the presence of a free market on a capitalist bias. To fully make use of the concentration of capital, the new commercial firms needed to address the whole of the urban population, either by extensively relying on publicity (grands magasins), by constructing a chain of stores spread over the city (maisons à succursales), by offering the possibility of mail ordering (ventes à

correspondance), or by a combination of those. Technically - before the breakthrough of conservation means such as canning or refrigerators - only the chain stores, dealing in smaller volumes and situated nearer to the customers, could cope with food products ${ }^{8}$, whereas the reliance of the others upon publicity would make them well suited for fashionable products. By the 1930s the field of retailing was cut up among no less than nine institutions. Numbers were still dominated by the traditional shopkeepers, and the divers formulas of ambulant commerce, such as peddlers or local markets. Exploiting the new possibilities for an economy of scale were, as mentioned above, the chain stores (food) and the department stores (non-food). The formula of mail ordering can be added here, though this sector was for the main part controlled by the department stores. Both the chain stores and the department stores were facing challengers, i.e. supermarkets and so-called fixed-price stores (magasins à prix uniques); both would more or less succesfully try to take over the new institutions, even if this involved a profound transformation of their firms. Dealing with economies of scale as well, but on a noncapitalistic bias, were the cooperatives - mostly socialist attempts to establish a counter-economy — and, in a lesser way, the so-called économats, collectivised sales points within administrations or firms ${ }^{9}$. By then, competition between the small shopkeepers on the one hand, and department stores and cooperatives on the other hand, had become harsh enough to induce the government to prohibitive measures. Yet, even the most complex typology could not capture the whole range of commercial initiatives in the retailing sector. The department store was never an isolated institution with clear-cut features. Most companies were somewhere halfway on a scale of continuously changing retailing formulas, combining both old and new techniques.

Third, the department store should be considered from a longer chronological perspective than merely the Belle Epoque. Extending its history into the twentieth century might illuminate the nature of the new sales machineries. In general, the evolution of the department stores during the twentieth century took place in three stages of expansion. The first wave of expansion was of a geographical kind. Following the lines of continuing 
urbanization, the stores appeared outside the capital in smaller cities and new regional centres. The immediate result of this was a conflict with local shops that were still growing to become grands magasins. At an intermediary stage, to cope with local competition, and to prepare for further expansion, the main department stores - as far as this had not yet been the case - took on the structure of a limited liability company. Financial groups were invited to bring in new capital. The second wave of expansion was of a social kind. The department stores opened up new chains of so-called magasins à prix uniques (fixed-price stores), offering common goods for daily use, thereby addressing a lower and much broader stratum of the population. This evolution reflected the growth of discretionary income in the first decades of the twentieth century ${ }^{10}$. Another intermediary stage followed. In order to concentrate more capital and to prepare for further expansion, the stores made the first moves in what would end up in a general fusion of companies. The third wave of expansion then was of a commercial kind. By opening up food departments in their chains of 'prix uniques' stores, turning them into 'supermarkets', the department stores entered the vast food sector in an attempt to take over the whole of the retailing sector. This was made possible only by a structural change in the internal economy of the households, where the introduction of the refrigerator went hand in hand with smaller families, car mobility and working wives. As a result of this, the nature of the department stores changed profoundly. Expanding into smaller towns, lower strata of customers, and the quite unfashionable food sector, the succesful combination of modernist bourgeois appeals serving commercial goals faced a divorce. As the stores entered the era of the supermarket, the low prices argument gained importance to the detriment of lifestyle arguments, clearly reflected in publicity efforts of an ever worldlier outlook. Finally, part of the debate around the definition of the department store is being obscured by a national perspective. Without denying the influence of regional customs, I find it highly questionable to consider these institutions while ignoring their urban nature. The advent of the grand magasin was never a French, American, British or German phenomenon, but common to the whole of the Western industrializing, urbanizing and capitalistic world. Its founders were bourgeois, owning some capital and belonging to a cosmopolitan social stratum. Its environment was the city, not the nation ${ }^{11}$. In other words, a department store, grand magasin or $\underline{\text { Warenhaus, }}$ was an urban institution in the first place, rather than a national one.

Drawing upon these remarks, I have investigated the twentieth century evolution of the grands magasins from an urban perspective. I deliberately selected a smaller provincial town somewhere in Europe (instead of the almost legendary companies of the major European capitals), more specifically Ghent, being the third of the five main Belgian urban agglomerations. Two aspects will be highlighted: firstly the institutional aspect, presenting an overview of the department stores present on the local scene, and their transformations during the period 19001960; and secondly I will analyse their advertising in local papers, in an attempt to capture some aspects of their changing nature. I have considered only those stores which (a) called themselves 'grand magasin', (b) offered goods of several various kinds, e.g. clothing and furniture, and (c) functioned on a turnover basis through organizing regular special sales (solden), finally (d) excluding stores with a preponderate food department (Delhaize), and cooperative societies (Vooruit) ${ }^{12}$.

\section{From grands magasins to supermarkets}

Ghent, as a provincial town of less than 250,000 inhabitants, was never really the place to be as to profitmaking for the department stores. Still, being one of the five main urban environments in Belgium, it provides a good average local scene. Before the First World War only one of the big three of the grands magasins was present: the Grands Magasins aux Nouveautés A l'Innovation. The scene for the department stores was still pretty much a local one. The oldest of the Belgian department stores, Au Bon Marché, stood strong in Brussels and felt like having covered the best of the Belgian market with branches in Liege and Antwerp. Still, its bourgeois customers becoming more and more mobile, the store judged it proper to advertise in local papers in Ghent at regular intervals. The Grand Bazar du Bon Marché in Antwerp was the successful second initiative of the founder of La Maison Universelle in Ghent. However, until the grand bazars of Liege and Brussels would associate with their colleagues in Antwerp and Ghent in 1920, La Maison Universelle would never quite grow above its local proportions. This did not mean that A I'Innovation was the only competitive department store in Ghent before 1920. As a matter of fact, it was facing quite a harsh competition from several local stores (displayed in italics in Table 1). 
Table 1 - Grands Magasins advertising in Ghent, 1900-1960

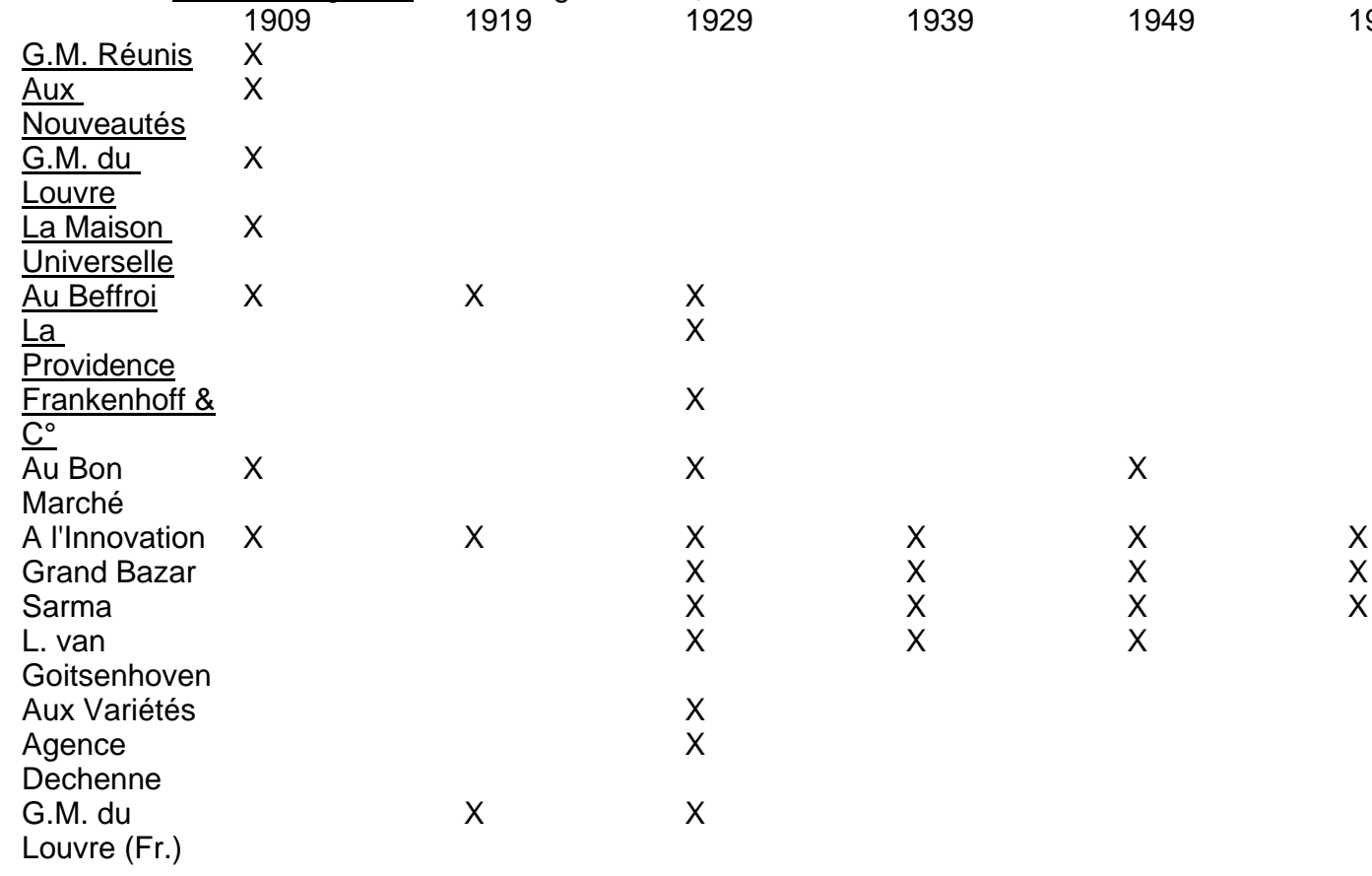


Apart from La Maison Universelle, founded in 1882 and predecessor of the later Grand Bazar ${ }^{13}$, we find six local competitors in Ghent claiming to be grands magasins. All of them were dating back from the nineteenth century, and would still be in the running after the First World War, though neither of them as department store anymore by that time. Each of them was presenting itself in 1909 as grand magasin, offering goods of different kinds, and taking part in clearance sales (solden) by the end of the season. Several of them were also, following the example of the Brussels' store Au Bon Marché, trying to gain some commercial advantage by imitating the names of famous French grands magasins. The background of the local department stores was initially a small shop, run by ambitious young tradesmen. By the end of the 1920s financial companies would step in and try to join the lucrative scene of the department stores. Still, none of the local stores would survive the crisis years of the early 1930s and the sharpened competition with the department stores from Brussels.

The local department stores came out of four different backgrounds. First, the most common origin of a department store was the fashion shop (maison de nouveautés). The Grands Magasins 'Aux Nouveautés' was founded in 1909 when O. Dupont took over E. Boulet's small fashion shop ${ }^{14}$, dating back from 189015. By 1929 however, it had shrunk again into a modest clothes' shop. The same happened to anothermagasin de nouveautés presenting itself in 1909 as grand magasin. K. Ledant's fashion shop Au Grand Louvre, founded around $1884^{16}$, proudly presented itself as the Grands Magasins du Louvre in $1909{ }^{17}$. The sought for confusion with the French department store of the same name was not much of a help though, as the shop turned out to have taken a step back after the First World War. A second type of shop was the haberdashery (mercerie). In Ghent only the Van Gheluwe haberdashery, in business since early $1866^{18}$, tried to become a department store. S. Van Gheluwe was advertising as the Grands Magasins Au Beffroi in $1909^{19}$, but died soon after. The shop was continued by $O$. Gevaert and remained competitive even by the end of the 1920s. A third type were the chinaware and crystal shops (magasins de porcelaines et cristaux). Les Grands Magasins Réunis Ad. Dangotte was dating back from $1883^{20}$, when Adolphe Dangotte seems to have taken over his father's business, a chinaware and crystal shop which was first mentioned in $1863^{21}$ by the local almanac. Adolphe Dangotte added household tools and furniture to the store's stock. In 1914 the shop was transformed into a limited liability company ${ }^{22}$, dealing with 'toutes opérations relatives aux arts décoratifs et ameublement'. It still existed after the First World War, but seemed to have withdrawn from the department store category. Finally, by 1929 two more local stores turned up. Both were credit houses (maisons de crédit) this time ${ }^{23}$, dating back from the beginning of the century. The Vlaamsch Crediethuis Frankenhoff et Co. was publishing rather modest, be it frequent, communications that could hardly be called advertisements. La Providence on the other hand, run by C. Vanex, seemed determined to conquer its part of the market, advertising abundantly. This last category was significant for a new interest in the retailing sector from the part of the financial world, coinciding with the transformations the Brussels' department stores were undergoing in this period. Yet none of the local stores would succeed in a breakthrough.

The local scene of department stores in Ghent was bound to be dominated by stores from other Belgian cities, mostly the capital, Brussels. Au Bon Marché, owned by the family Vaxelaire, was the first Belgian grand magasin, in business since François Vaxelaire and his wife took over a store of the Thiéry brothers in 1866. Its home town was Brussels, and with branches opening up between 1881 and 1886 in Liege and Antwerp, the major cities in Belgium were being covered. The store prospered, and by the turn of the century it had left all of its competitors at a safe distance. The Vaxelaires seem to have become even a little too confident, for Au Bon Marché would not show much innovative enthusiasm anymore. Innovation then, was the name of the Grands Magasins aux Nouveautés A I'Innovation, founded in 1897 by Jules Bernheim and the Meyer brothers, right beside Au Bon Marché in Brussels' main street. The store showed very dynamically, addressing itself to a broader range of customers and opening up no less than seven branches in the following decade, among which in Liege, Ghent and Antwerp. The third main department store of the period finally, knew a rather complex early history. Grand Bazar was the name in 1885 of the Antwerp store of Adolph Kileman, the founder of La Maison Universelle in Ghent in 1882. It was also the name of August Tiriard's store in Liege, founded in 1885, and of the limited liability company founded on his initiative at the Brussels' Boulevard Anspach two years later ${ }^{24}$. In the years to come the three companies would become financially intertwined.

What these stores had in common was that they did not grow out of smaller shops, but were founded directly as department stores ${ }^{25}$. By the beginning of the twentieth century they had already undergone a first wave of expansion: Au Bon Marché had three branches, A l'Innovation seven and the Grands Bazars four. This type of expansion would continue all throughout the century.

In 1920 some important developments would prepare the department stores for a second wave of expansion. First of all, Bernheim would succeed in taking over the giant department store of German origin Tietz in Brussels, beating its opponent Au Bon Marché with an all-or-nothing bid of 36,5 millon francs ${ }^{26}$. The operation was prepared by having financial groups from Brussels taking share in the store's new form as a limited liability company27. Still, Bernheim's A l'Innovation was almost ruined, struggling for several years to overcome its debts. But when it finally did, the reborn A l'Innovation as good as equalized the size of Au Bon Marché. A second event took place the same year when Victor Tiriard succeeded in connecting his Grands Bazars of Liege and Brussels to those of Ghent and Antwerp by taking an important share in the newly founded limited liability company Grands Bazars Réunis Anvers-Gand28. Au Bon Marché was rather late to react to these developments, turning into a limited liability company as late as $1927^{29}$. Having attracted new capital, the department stores were ready for a new type of expansion.

A new formula was being prepared for the department stores. The magic word was prix uniques. The principle of prix uniques meant that sales would be concentrated on basic issues, articles that were certain always to sell in very high quantities, combined with very low profit margins, and a minimum of general expenses (sober architecture and a high degree of self-service) $)^{30}$. In other words, the new stores were radicalizing the rational 
principles of sales organisation that allready had been constitutive to the grands magasins in the previous century. But while the grands magasins had concentrated on luxury articles, addressing the most obvious part of the market, the wealthy bourgeois, the magasins à prix uniques offerred simple products for daily use, addressing a much broader part of the population. 'Prix uniques' was not a European invention. It went back to the American fixed-price stores, e.g. Woolworth's 'five and ten cents'. While it originally meant that all products offerred were within a specific, low price category, it seemed only a matter of time before the new stores would overlap with the grands magasins. By the 1930s most European countries had their chain of fixed-price stores ${ }^{31}$. The first initiative in Belgium came from Jean Van Gijsel, creating Sarma, a limited liability company, in $1928^{32}$. The creation of Sarma, as a fourth big name in the world of the Belgian grands magasins, caused some consternation, as both Bernheim and Vaxelaire understood very well the possibilities inherent in the new formula. Vaxelaire's Au Bon Marché was the first to react, with the creation of its own fixed-proce store in 1929, while Bernheim tried to set up an international structure around A I'Innovation ${ }^{33}$. Both failed, however, and neither of the two seeming capable of formulating an answer to the Sarma challenge, in 1933 the old rivals decided to fuse their supermarket initiatives into Prisunic-Priba ${ }^{34}$. Even then, while the Grands Bazars were to remain absent from the new scene, PrisunicPriba would find it hard to get ahead of Sarma, as the leaders of the old grands magasins found it not easy to lay off the old skin and apply the prix uniques principle in a consistent way - hesitations of this kind Jean Van Gijsel being unaware of in his brand new company.

Yet, before the war of the department stores was about to fully break loose, the Belgian government decided to interfere. The international economic crisis of the early 1930s had intensified the complaints of the traditional sector of small shopkeepers against the new retailing structures, pushing the governments of several European countries to take prohibitive measures ${ }^{35}$. The Loi de Cadenas (Padlock Law) was passed early 1937, forbidding expansion of the department stores of any sort. Not until the end of 1960 the prohibition would come to an end ${ }^{36}$, in the meantime slowing down movements in the world of the grands magasins (though the stores proved to be rather creative in getting round the prohibitive measures on several occasions $)^{37}$.

Slowly, the department stores would be integrating food departments in their fixed-price stores, thereby entering a third wave of expansion. By 1960 the sector of the department stores had become somewhat simplified. First of all, Sarma had not realized the breakthrough, lapping behind of the big three. Jean Van Gijsel had left the board of directors, to join the Grands Magasins de la Bourse, the only independent grand magasin of the old days remaining. Notwithstanding a careful form of cooperation Sarma-Bourse was to stay on a humble fourth place. The three main stores, Au Bon Marché, A I'Innovation and the Grands Bazars, had shaken off all of their competitors, but the rank order had changed since 1929. 
Table 2 - The main Grands Magasins compared 1929-195938

\begin{tabular}{|c|c|c|}
\hline \multirow{2}{*}{\multicolumn{3}{|c|}{ Capital }} \\
\hline & & \\
\hline Au Bon Marché & 40 & 216 \\
\hline A l'Innovation & 75 & 210 \\
\hline Grands Bazars & 48 & 194 \\
\hline \multicolumn{3}{|l|}{1959} \\
\hline Au Bon Marché & 200 & 1413 \\
\hline A l'Innovation & 600 & 1969 \\
\hline Grands Bazars & 370 & 2364 \\
\hline
\end{tabular}

Gross Profit

9

18

14

10

6

$67 \quad 5$

$93 \quad 12$

$61-19$

\section{Branches}

12
19 
While the Grands Bazars had done very well, becoming the leading department stores by 1959, and A I'Innovation had managed to maintain its second position, Au Bon Marché had lost its leading position and was even getting seriously behind of the two others. Therefore it was no surprise that it would be the Grand Bazars to realize the breakthrough in the transformation of the grands magasins into supermarkets. Perhaps the complex structure of the Grands Bazars affiliation had slowed down the developing of their own chain of supermarkets. In 1960 the Grand Bazar d'Anvers ${ }^{39}$ decided to go on its own, creating G.B. Supermarchés ${ }^{40}$. While the Grands Bazars of Liege and Brussels drifted away as the affiliation was falling apart, the Antwerp bazar was making its own success-story. The fusion in 1968 of the old Grand Bazar d'Anvers into its own supermarket chain ${ }^{41}$ was to mark the symbolic and final end of the era of the grands magasins. As the gap was widening, the former rivals of A I'Innovation and Au Bon Marché faced no other way out but a fusion. The newly created Inno-BM in 1969 was worth one and a half billion francs ${ }^{42}$, but as its supermarket chain Priba-Unic was still lagging behind, within a few years it had lost its leading position again to the rapidly growing G.B. Entreprises.

Still, the department stores used to be not the only retailing companies. There had also been the maisons à succursales, loosely affiliated chains of food stores, and the cooperative societies, mostly socialist attempts to create a counter-economy. One of the former, Delhaize-De Leeuw, was not to sit quietly as $\underline{G}$.B. Entreprises was trying to take over the whole of the retailing market, including the food sector. Very soon, G.B. Entreprises considered it wise to enter a fusion with the former competitors of Inno-BM, creating GB-Inno-BM in 197443. In 1987 finally, Sarma, which had been taken over in 1969 by an American multinational, J.C. Penney, was to join the ranks of GB-Inno-BM. Everything had come together: as the grands magasins had been expanding according to the supermarket/prix uniques principle, they had not only conquered a greater part of the retailing market in all of its sectors, they had also lost their former modernist identity, until only the purely commercial principle remained: the bigger you are, the more you will get, leading them into a general fusion.

\section{Advertising in Local Papers: Some Remarks}

In a paradoxal way, advertising appetite was shrinking as the stores were expanding. The highest degree of publicity fever was being reached in the late $1920 \mathrm{~s}^{44}$. There has probably never been more advertising in Belgian history than during these years, with the exception maybe of the present decade. The four main department stores were facing severe competition from two sides, both from the old local shops, in their last attempt to conquer a place on the grands magasins scene, and from new companies on a national scale, as the ever growing consumer market had attracted attention from the side of capital-owners. Among the latter (category 'Others' in Figure 1) we notice the Etablissements Louis Van Goitsenhoven, owned by a captain of industry of modest scale specialized in cinema, gramophones, photography etc., as well as Aux Variétés, a chain with no less than 24 branches in 1929, owned by the family De Baerdemacker. The line of evolution towards a peak in 1929 is to become clearer if the war difficulties both in the first half of 1919 and the second half of 1939 are taken into account, reducing publicity efforts almost to zero. The diminishing advertising activity after 1929 is mainly due to the lower pressure of competition. The local stores were being wiped off the market, soon to be followed by all other competitors of the old grands magasins, with the notable exception of Sarma. All of this was in sharp contrast with the case of Brussels, where competition remained fierce all throughout the period.

Whereas in 1909 the local stores were still dominating the local publicity scene, to the detriment of Au Bon Marché and A I'Innovation, this had gone done to one third by 1929, and was reduced to zero a decade later, as department stores in Ghent had outgrown the local level. The four main department stores were facing a new challenge from 1929 on, the market being split up into three, with local stores, the four main grands magasins, and the other department stores equalizing each other. By 1939 however, the 'big four' had recaptured a major part of the market, while after the Second World War they shared a virtual monopoly in department store advertising. As Au Bon Marché did not dispose of a branch in Ghent, and Sarma was according to the prix uniques principle less inclined to maintain an image through advertising, it was A l'Innovation and Grand Bazar fighting it out from 1929 on. The dominance of Grand Bazar seemed established by 1959, mirroring the commercial successes of the store. Remarkable in 1959 finally, is the entry of the first maison à succursales, Delhaize, in the department store publicity, presenting large and abundant advertisements, almost exact copies of the style the former grands magasins had been displaying up till then.

A notable difference between the main department stores and their competitors on both the local and the national level occurs when comparing the frequency of publishing of a single ad. The commercial successes of the former in the long run might also be explained by the elaboration of their advertising strategies. The main grands magasins took the trouble of adapting their publicity messages to the concrete commercial occasions they were advertising, thereby covering a much broader array of arguments and motives for buying towards the public, whereas their competitors employed much more general ads, being published over and over again.

The frequency rate of the four main department stores is remarkably consistent all throughout the covered period, the average always below three, whereas the others are scoring averages of up to twenty. After the Second World War ads being published more than once have become exceptional.

The same conclusions apply when considering the size of the advertisements. The size of the advertisements seems to be dropping when a store feels its competitive force slipping through its fingers, as with the local stores after the First World War, the national competitors after the Second World War, and Sarma in 1959. Still, as a rule the advertisements of the department stores were large size $e^{45}$, illustrating the importance that was being attributed to advertising. By 1959 a small size ad had become almost unthinkable to the department stores.

Faithful to their roots as maisons de nouveautés, the fashion seasons were still dominating the advertising practices of the grands magasins. The month of June, the yearly occasion for solden (clearance sales) 
was traditionally a peak period as for publicity. October on the other hand was the beginning of the new season and the main sales month. Lesser highdays for commercial publicity were the end of November with Sinterklaas ${ }^{46}$; the end of December and the beginning of January, as Christmas and New Year's day were shaking hands with the wintersolden; while the end of August and the beginning of September seemed a good opportunity to sell some school accessories. In May any occasion was good enough to end the low season: Mother's Day, Communion, Pentecost or even Easter, spring cleaning or the first warm days.

The common profile of a department store advertisement thus appears as a large ad, created for a special occasion, which was often solden. Still, even in the low season advertising never quite fell away, as the difference in advertising intensity between high and low season was permanently less than five percent. Going deeper into the occasions for which advertisements were published, an evolution becomes clear. Whereas solden was the motive for almost half of the advertisements in 1909, by the end of the covered period it had dropped to less than ten percent. Advertisements for special occasions, such as Communion, Easter, the new school year, Santa Claus, Christmas etc., were following more or less the same line. Publicity for specific departments or a limited array of articles on the other hand was dominant from 1929 on and had become the standard by 1959. In other words, as the scope of the department stores was expanding from an emphasis on fashionable articles to the whole of the retailing market, the stores were becoming less and less dependent on seasonal turnover, and more and more inclined to build an image through specific wares as to compensate for the loss of their modernist identity.

An interesting matter, finally, is the question as to what kind of customers the department stores were addressing through their publicity. The advertisements do not provide a convincing answer here, as references to customers are either absent, or deliberately up-scaled to one level above the actual social situation of the potential client. However, as I chose to consider two papers situated in complementary social settings, the number of advertisements being published in only one of the two papers might be an indication of the kind of customers the department stores were aiming at. Among the local papers in Ghent we find La Flandre Libérale, addressed to the liberal, French-speaking bourgeoisie, and Vooruit, a Dutch-speaking socialist worker's paper.

The results as displayed in Figure 6 are probably exagerated, as the French-speaking paper had become quite outmoded after the Second World War, and was much less interesting for advertisers. Notwithstanding this, the evolution is quite clear, and illustrative of another expansion.

\section{The Seduction of the Consumer Through Advertisements}

Following the line of argument Marchand is developing in his remarkable analysis of American advertising in the 1920s and 1930s, modern advertising should be seen as undergoing a fundamental change after the First World War ${ }^{47}$. Product-oriented ads, rationally stressing the utility dimension of a product, were gradually being replaced by consumer-oriented ads, emotionally underlining the pleasure dimension of an article. The most primitive form of the former kind was the so-called brand-name publicity, simply depicting the brand name of the product, incidentally accompanied by a view of the factory or its owner. A somewhat more sophisticated variant was the reason-why technique, including a text which summed up all sorts of arguments why the article should be bought. The main disadvantage in this line of advertising was its rational character, inviting the consumer to rationally consider the arguments, thereby opening up the possibility for the latter to come up with counter-arguments. A much more efficient way of treating the client was to make an appeal to his or her emotions, detracting the attention from the product by stressing the effects the article could have upon the life of the consumer rather than the inherent qualities of the product. In other words, what counted was seducing the customer, selling sex instead of soap, personality instead of a hat, or adventure instead of lemonade. In order to avoid any rational considerations, and to maximalize the appeal to the consumer, pictures were by far preferred in this kind of advertising above text.

It would not be unreasonable to suppose that as commercialization was expanding with the department stores, some of the transformation mentioned above was likely to show up in their publicity. Were they emphasizing product-oriented or consumer-oriented advertising? If we assume a price-list included in the ad to be a basic form of reason-why approach, and the presence of graphical elements as to be attempts to seduce the consumer, then the answer is 'both', as shown in Figure 7.

The switch seems to have occurred during the 1920s, paralleling the evolution in American advertising as described by Marchand. The common use of graphics in an advertisement was a handful of drawings of models showing off the clothing mentioned in the accompanying price-list. Sceneries from the life of an average consumer detracting attention away from the product were rather exceptional, only to be found well after the Second World War. The grands magasins, as contrasted with the role they seemingly fulfilled before the turn of the century, were no forerunners as to modern advertising. Part of this should be attributed to the prix uniques principle: as the department stores intended to maximalize the possibilities of an economy of scale flowing from the concentration of capital in their hands, attention was being concentrated upon the low price argument. Therefore the price-list technique, introduced by A I'Innovation as early as 1909, was not to lose importance as modern advertising found its way to the Belgian publicity scene, quite the contrary.

In 1909 we find the department stores disposing of the largest and most frequent advertisements in the papers, as such leading the publicity scene. Still the contents of these ads are certainly not innovating. Forerunners in this period as for the latest advertising techniques are the pills and powders of the quack medecine kind, introducing huge slogans, cartoons, seductive illustrations and even the first modest photographs. Generally speaking stores are much more present on the publicity market, but brand-names are offering the most innovative ads (Figure 8). One modest example of graphical advertising is found in the Santa Claus ad of $A$ I'Innovation with its title in calligraphic setting (Figure 9). 
By 1919 the same store seems to have reached a sort of standard lay-out for its advertisements. An average department store ad of these years consisted of a frame, in which the huge logo of the store was followed by a smaller heading, and surrounded with a price-list (Figure 10). A decade later we notice a breakthrough of graphical elements, adding font effects and illustrations to the former concept (Figure 11). Thereby a standard was set surviving up till today, be it that the drawings were replaced by photographs after the Second World War, taking in an ever growing share of the ad's surface.

Yet A I'Innovation was certainly not the most progressive of the department stores. Its main challengers Sarma and Van Goitsenhoven were much more eager to integrate graphical elements in their ads from 1929 on. One of the consequences of the rapid transformation of advertising techniques in these years was the cooperative societies getting seriously behind. Until then the latter had taken care of following the department stores publicity efforts by nearby, to the extent that the freethinking Vooruit did not hesitate to advertise the celebration of the catholic feast of Communion, or simply to counterfeit the more elaborate ads of the department stores.

The stores were still prominently present in 1929, but they were beaten this time by a range of technological products entering the mass-market, especially radios, cigarettes, kitchen-ranges and vacuum cleaners. But most of all these were the automobile years, in for almost half of the publicity market, while cosmetics and hygiene articles had followed up the pills and powders in the quack sector. In this wilderness of publicity, the grands magasins were good followers, but never fore-runners. Several of the modern advertising techniques mentioned by Marchand were being applied, e.g. elaborated reason-why, endorsements of famous people, or scare cope pointing out what could happen if the consumer would not buy the product. More was to come in the following decades, such as the use of comics to picture daily scenes from the consumer's life, radiant beams of sacral light coming out of the sky as icons of the advertising world, or ads disguised as editorial copy. Yet the grands magasins would go their own way.

Several other strategies were tried out. Au Bon Marché introduced a formula in 1927 whereby visitors from out of town could have their traveling expenses covered by the store if spending a certain amount of money there. La Providence soon followed the example, some time later followed by A l'Innovation. The latter store then again was well known for its in-built tea-room, offering its customers the full scale of the enjoyments a day out should offer. A l'Innovation was also supplementing its advertisements by tiny communications in the small ads sector of the paper. Finally, in this period several of the department stores were diversifying their advertising strategies as different advertisements were being created according to the public aimed at, an experiment however that was not to be prolonged in the following years.

By 1939 Grand Bazar had become the most innovative of the department stores, regularly experimenting with recognizable illustrations, intriguing headings or slogans of striking proportions (Figure 12). Still the abundant style of advertising of the 1920s was soon to disappear: the decrease of publicity in the papers in Ghent after 1929 is striking. Eventually by 1959 even the cinema announcings had become tiny. Moreover, several advertisements that year prove to be a copy of those used a decade earlier. The only change here was the final breakthrough of photographs instead of drawings as the main source for illustrations. By then the grands magasins had settled in a two-hearted advertising strategy: sober price-lists accompanied by genteel models, icons for female seduction. As such the newborn supermarket owners found a compromise, convincing through low prices and seducing through genteel images, thereby paying a last tribute to their modernist roots with the 'genteel classes' of the nineteenth century.

\section{Conclusion}

As argued above, the specific historical role of the grands magasins follows directly out of their capacity to fuse modernist bourgeois culture and commercial mass production into a dream marriage. The commercialization of modernism took place in the heyday of the department store, the last decades of the nineteenth century.

From the 1920s on, a major change was taking place. As consumption was on the rise, paralleling the welfare society coming into being, the department stores, with a high concentration of capital in their hands, were not to remain indifferent. Following the prix uniques principle, expansion was to take place on three levels. Geographically webs of ever more local branches were created; commercially the emphasis upon fashionable goods faded away as basic products like food stuff were taken in; and finally socially the department stores were to come out of their bourgeois background, addressing themselves to a much broader stratum of the population.

By 1960 the transformation of the former grands magasins had become irreversible, destroying most of the historical identity of the stores, and leading them into a confrontation with the maisons à succursales. Still, as contrasted with the end of the nineteenth century, during this second phase of the development of a consumer society from the 1920s on, the grands magasins were no longer fore-runners, merely good followers as stores in general were making way for brand-names on the publicity market. Still, paying a last tribute to their social and cultural roots, the grands magasins found a compromise in an advertising style of their own, convincing through low prices and seducing through genteel images.

(1995), pp. 3-4

${ }^{1}$ Bill Lancaster, The Department Store: A Social History, London: Leicester University Press

2 Paul Glennie, 'Consumption Within Historical Studies' in D. Miller (ed.), Acknowledging consumption: A Review of New Studies, London: Routledge (1995), pp. 189-190.

${ }^{3}$ Colin Campbell, The Romantic Ethic and the Spirit of Modern Consumerism, Oxford: Blackwell (1990), p. 94. 
${ }^{4}$ Neil McKendrick, The Birth of a Consumer Society: The Commercialization of EighteenthCentury England, London: Europa Publications (1982), p. 12.

${ }^{5}$ Rudi Laermans, 'Learning to Consume: Early Department Stores and the Shaping of the

Modern Consumer Culture', Theory, Culture and Society, 10, 1993, p. 82.

${ }^{6}$ Rosalind H. Williams, Dream Worlds: Mass Consumption in Late Nineteenth-Century

France, Berkeley: University of California Press (1982), pp. 58-106.

${ }_{7} \mathrm{H}$ [rant] Pasdermadjian, Le grand magasin: son origine, son évolution, son avenir, Paris:

Dunod (1949), pp. 1-9.

${ }^{8}$ Gerrylynn K. Roberts, 'Food', in C. Chant (ed.), Science, Technology and Everyday Life 1870-1950, London: Routledge/The Open University (1990), pp. 250-256 and 258-260.

${ }^{9}$ Fernand Simonet, Le petit commerce de détail: sa lutte avec le grand commerce de détail, Louvain/Paris: Ecole des sciences commerciales et économiques/Librairie d'économie commerciale (1934), pp. 25-67.

${ }_{10}$ Peter Scholliers and Chris Vandenbroeke, 'The Transition from Traditional to Modern

Patterns of Demand in Belgium', in H. Baudet and H. van der Meulen (eds.), Consumer Behaviour and Economic Growth in the Modern Economy, London: Croom Helm (1982), p. 41.

${ }^{11}$ Siegfried Gerlach, Das Warenhaus in Deutschland: Seine Entwicklung bis zum Ersten

Weltkrieg in historisch-geographischer Sicht, Stuttgart: Steiner Verlag (1988).

12 Typology used by the National Bank of Belgium in the 1930s, Bulletin d'information et de documentation, 8,1933 , p. 370 .

${ }^{13}$ Serge Jaumain, Les petits commerçants belges face à la modernité (1880-1914), Brussels: Editions de l'Université de Bruxelles (1995), p. 48.

${ }^{14}$ Dubbele wegwijzer der Stad Gent en der Provincie Oost-Vlaanderen, 47, p. 558.

15 Dubbele wegwijzer, 28, 1890, p. 466.

${ }_{16}$ Wegwijzer der Stad Gent en der Provincie Oost-Vlaanderen, 115, 1884, p. 468.

17 Dubbele wegwijzer, 47, 1909, pp. 519-520.

${ }^{18}$ Dubbele wegwiizer, 14,1866, p. 429.

19 Dubbele wegwijzer, 47, 1909, p. 513.

20 Wegwijzer, 114, 1883, p. 466.

21 Wegwiizer, 94, 1863, p. 439.

22 Dubbele wegwiizer, 53, 1915 , p. 479.

23 Dubbele wegwiizer, 47, 1909, p. 441.

24 Jaumain, Petits commercants, pp. 47-48; Jacques Roets, La structure fonctionnelle des grands magasins, Brussels: Ecole professionnelle de vente (1944), p. 107; Mireille Servé, 'Grands magasins et publicité à la fin du XIXe et au début du XXe siècle', Cahiers de Clio, 1988, 95, pp. 1520.

${ }^{25}$ Though at their very origin Au Bon Marché reminded of a fashion shop, while A l'Innovation showed some characteristics of a more modest haberdashery.

26 Jacques Lacrosse and Pierre De Bie, Emile Bernheim: Histoire d'un grand magasin,

Brussels: Labor (1972), pp. 55-58.

${ }^{27}$ Recueil financier, 37, 1930, 1, p. 764.

${ }_{28}$ Recueil financier, $37,1930,3$, p. 1155.

${ }^{29}$ Recueil financier, $38,1931,1$, pp. 861-862.

30 Simonet, Petit commerce de détail, p. 31; Pasdermadjian, Grand magasin, pp. 38-39; Noël Cassé, Etude sur les grands magasins à prix uniques, Paris: Rousseau (1935), pp. 9-11 and 21-22.

${ }^{31}$ Besides the American stores Woolworth, Kresge, Kress and McCrory, we find Woolworth and Marks \& Spencer (England); Woolworth, Wohlwert, EPA (Einheitspreis AG) and EHAPE (Germany); Unifix, Monoprix, Prisunic and Priminime (France); UPIM (Unico Prezzo Italiano Milano) and TAPU (Tutto A Prezzo Unico) (Italy); TIC (Towary Jednolitych Cen) (Poland); ASO (Ander \& Sohn), JEPA and TETA (Czechoslovakia); HEMA (Hollandse Eenheidsprijzen Maatschappij) (Netherlands); SARMA and Uniprix-Priba (Belgium); EPA (Enhetsprisaktielobaget) (Sweden); and Einheitspreis and Uniprix (Switzerland). Also Takashimaya (Japan). Simonet, Petit commerce de détail, p. 32.

32 Recueil des actes et documents relatifs aux sociétés commerciales (Annexes au Moniteur Belge), 21-22 July 1929, pp. 932-933. 1393-1394.

33 Lacrosse and De Bie, Emile Bernheim, pp. 91-97; Recueil des actes, 5-6 March 1934, pp.

${ }^{34}$ Presently known as Unic.

35 First measures in Germany and Austria, 1932 and 1933. Refused by the American Congress in 1934, but accepted in France after a long debate, 1933-1936. Simonet, Petit commerce 
de détail, pp. 103-109. First demands in Belgium before 1934, parliamentary proposals from 1936 on. Les magasins à prix uniques: au triple point de vue du consommateur, de l'industrie et du petit commerce, Brussels: Sarma (1934); Rapport des Représentants des Grands Organismes de Distribution à la Commission du Commerce de Détail, Antwerp: Chambre syndicale des Grands Magasins de Belgique (1937).

36 'Loi interdisant l'ouverture ou l'agrandissement de certains établissements de vente en détail' of 13 January 1937, prolonged by the laws of 25 March 1937, 17 June 1937, 1 April 1938 (modified) and 26 December 1938, and by the Royal Warrant of 29 July 1939. Further prolonged during the Occupation, 1940-1944. Prolongation continued by the laws of 10 September 1945, 23 December 1946, 28 February 1947 and 30 December 1947 (modified). New temporary loi de cadenas on 12 May 1948, and again on 3 March 1954. The latter expired March 1959 (after a law project of 27 November 1956 failed to get through the parliament), but Minister Paul Vanden Boeynants agreed with the department stores to maintain the prohibition until 1 January 1961. Pasinomie, 1936-1960; René Evalenko and Marcel Michel, La structure du commerce de détail en Belgique et la législation de cadenas, Brussels/Louvain: Institut de sociologie Solvay/Centre de recherches en économie et gestion des entreprises (1958), pp. 16-27; Lacrosse and De Bie, Emile Bernheim, p. 137.

37 Leading Sarma to develop another supermarket chain, Nopri.

${ }^{38}$ All figures (except the number of branches) in millions of Belgian francs. Figures for the Grands Bazars are the results taken together of Grands Bazars Réunis Anvers-Gand, Grand Bazar du Boulevard Anspach (Brussels) and Grand Bazar de la Place St.-Lambert (Liege). Recueil des actes, 25 December 1929, pp. 3889-3890 (A I'Innovation, situation on 31 July 1929) and 28 June 1930, p. 5319 (Au Bon Marché, situation on 31 December 1929); Recueil financier, 37, 1930, pp. 1157, 1159 and 1447 (Grands Bazars, situation on 31 January 1930), and 66, 1959, p. 4001 (Au Bon Marché, situation on 31 July 1959), p. 3971 (A I'Innovation, situation on 31 July 1959) and pp. 28612873 (Grands Bazars, situation on 31 January 1959).

39 Formerly the Grands Bazars Réunis Anvers-Gand, which had its name changed in 1933 to Galeries du Bon Marché and again in 1941 to Grand Bazar d'Anvers/Grote bazar van Antwerpen.

${ }^{40}$ Recueil financier, 73, 1966, p. 2128.

41 Recueil financier, 77,1970, pp. 2264-2265.

42 Recueil financier, 77,1970 , pp. 2104-2105.

43 Recueil financier, 81,1974, p. 1241.

${ }_{44}$ Data on advertisements taken from an investigation of La Flandre libérale, $1909-1959$ and Vooruit, 1909-1959.

${ }^{45}$ Any ad with a size equal or superior to DIN A5 (half of a standard copy sheet) was considered large size.

${ }^{46}$ Santa Claus in Ghent, celebrated the 6th of December.

${ }^{47}$ Roland Marchand, Advertising the American Dream: Making Way for Modernity, 1920-1940, Berkeley: University of California Press (1985), pp. 1-24. 